\title{
Effect of brine composition and brining temperature on cheese physical properties in Ragusano cheese
}

\author{
N. Fucà, ${ }^{* 1}$ D. J. McMahon, $†$ M. Caccamo, ${ }^{*}$ L. Tuminello, ${ }^{*}$ S. La Terra, ${ }^{\star}$ M. Manenti, ${ }^{\star}$ and G. Licitra ${ }^{\star} \ddagger$ \\ ${ }^{*}$ CoRFiLaC, Regione Siciliana, Ragusa 97100, Italy \\ +Western Dairy Center, Utah State University, Logan 84322 \\ ¥Dipartimento Scienze Produzioni AgroAlimentari (DISPA), Catania University, Catania 95123, Italy
}

\begin{abstract}
Composition and physical properties of cheeses are influenced by temperature, salt, and calcium concentration of brine. This work aimed to examine conditions of brine under which the cheese matrix contracts or expands in absence of restrictions imposed by surface rind development during overnight block formation. Three experimental 4-kg blocks of Ragusano cheese were produced at 3 different stretching temperatures $\left(70,80\right.$, and $\left.90^{\circ} \mathrm{C}\right)$ and cut into pieces weighing approximately 40 to $50 \mathrm{~g}$. One piece from each was chemically analyzed at time 0 . All other pieces were measured for weight and volume and placed in plastic bags containing $300 \mathrm{~mL}$ of different brine solutions $(2 \% \mathrm{NaCl}$ with $0.1 \% \mathrm{Ca} ; 10 \% \mathrm{NaCl}$ with $0,0.1,0.2$, or $0.4 \% \mathrm{Ca} ; 18 \%$ $\mathrm{NaCl}$ with $0.1 \% \mathrm{Ca}$; and $26 \% \mathrm{NaCl}$ with $0.1 \% \mathrm{Ca}$ ) at 3 different temperatures $\left(4,12\right.$, and $\left.20^{\circ} \mathrm{C}\right)$. After $24 \mathrm{~h}$ of brining, the cheeses were analyzed for weight, volume, chemical, and microstructural changes. Salt concentration in brine significantly influenced composition, weight, and volume of the cheeses after brining. Salt concentration was inversely related to cheese volume and weight. Changes in weight caused by altering the brining temperature were sufficient to reach statistical significance, and statistically significant volume changes were induced by brining temperature and its interaction with salt content. The highest volume increase (30\%) occurred in the cheese stored in the $2 \%$ $\mathrm{NaCl}$ brine at the coldest temperature, whereas the greatest volume decrease was recorded in cheeses brined in the $26 \% \mathrm{NaCl}$ brine. Composition was not affected by brining temperature. Calcium concentration did influence weight, volume, and composition, except on a fat-on-dry-basis. When cheeses were brined without added calcium, cheese volume and weight increased at all temperatures. At high calcium levels $(0.4 \%)$, syneresis occurred and volume decreased, especially at $20^{\circ} \mathrm{C}$
\end{abstract}

Received April 12, 2011.

Accepted September 30, 2011

${ }^{1}$ Corresponding author: fuca@corfilac.it
$(-16.5 \%)$. Microstructural investigation with porosity measurement confirmed weight and volume changes.

Key words: cheese microstructure, temperature, salt, calcium

\section{INTRODUCTION}

Ragusano cheese is a traditional Sicilian cheese made from raw cow milk in the province of Ragusa (Licitra et al., 1998). Ragusano is a pasta filata cheese produced using traditional wooden tools in which microorganisms from a biofilm in a wooden vat acidify the milk and coagulation occurs by adding of rennet paste (from kid and lamb; Licitra et al., 2007). Curd is heated, drained, reheated in whey or water, drained, and then allowed to acidify overnight at ambient temperature. The fermented curd is stretched in hot $\left(\sim 85^{\circ} \mathrm{C}\right)$ water into a coherent mass to produce a smooth surface, and then pressed into a rectangular block. Typically, 16-kg bocks are immersed in saturated salt brine at ambient temperature for $3 \mathrm{wk}$, after which they are aged up to 12 mo without vacuum packaging at ambient temperature. Two blocks of cheese are tied together with rope and hung over rafters to facilitate even moisture loss from the blocks (Licitra et al., 1998).

Changes in cheese composition during brining are typically a balance between weight gain resulting from salt penetration into the cheese and weight loss as moisture exits the cheese (Geurts et al., 1974). Swelling or shrinkage of the cheese that is dependent on both the salt and calcium content of the brine may also occur (Geurts et al., 1972). For Gouda cheese brined at $12^{\circ} \mathrm{C}$, the crossover salt concentration at which no change in cheese volume occurred was approximately $15 \%$ (wt/ wt) when the brine contained $0.1 \%$ (wt/vol) calcium. When calcium content was increased to $0.5 \%$ (wt/vol), cheese samples contracted when the brine salt concentration was $>8 \%$. At lower salt concentrations, the cheese expanded. For some cheeses, such as Feta, temperature of the brine solution and $\mathrm{pH}$ of the cheese can also influence changes in weight and volume of cheese during brining (McMahon et al., 2009). At low temperatures (e.g., $\leq 6^{\circ} \mathrm{C}$ ), cheese volume increases when 
Feta is immersed in brine with salt concentrations of 6.5 to $9.5 \%$ (wt/wt) and calcium content of $0.1 \%$ (wt/ wt), whereas shrinkage occurs at higher temperatures $\left(22^{\circ} \mathrm{C}\right)$. When Feta cheese is brined at $10^{\circ} \mathrm{C}$, whether the cheese gains or loses volume depends on brine salt and calcium concentration, brining temperature, and initial $\mathrm{pH}$ of the cheese (McMahon et al., 2009).

Penetration of salt into cheese during brining has been described as an impeded diffusion process (Guinee and Fox, 2004). When a block of cheese is placed into brine, there is a net movement of $\mathrm{Na}^{+}$and $\mathrm{Cl}^{-}$ions from the brine into the cheese. Ions such as $\mathrm{Ca}^{2+}$ and $\mathrm{H}_{2} \mathrm{PO}_{4}^{-}$move into the brine if their concentration is higher in the cheese than in the brine. If the osmotic pressure difference between the cheese and the brine is sufficiently high, then water molecules will also diffuse out of the cheese. Geurts et al. (1974) determined that, in general, water moves out of the cheese about twice as fast as salt moves into the cheese because of the diffusion process. They proposed that such water displacement is not a result of independent shrinking of the matrix but rather that the reduction in volume follows from the net transport of water and salt. However, the observation by McMahon et al. (2009) that cheese can shrink or expand when cheese in a brine solution is moved from cold to warm or from warm to cold temperature implies that the inherent properties of cheese are just as important as the osmotic effects. Changes in cheese volume can thus occur in the absence of any salt concentration gradients between cheese and the surrounding brine.

Traditionally, Ragusano cheese has been brined in a saturated salt solution at ambient temperature, and loss of moisture from the cheese is greater than absorption of salt, resulting in an 11\% decrease in cheese weight (Licitra and Bottazzi, 2001). Subsequent storage for 12 mo produces a further $6 \%$ moisture loss. The greatest changes in salt and moisture occur at the surface of the cheese block and a surface barrier layer is formed. It has been calculated that the porosity of the exterior 1-mm portion of Ragusano cheese blocks decreases by approximately $50 \%$ after immersion in saturated brine for $12 \mathrm{~d}$ (Melilli et al., 2005).

Achieving rapid salt penetration into the cheese is important because if the salt content in the interior of the block of Ragusano cheese remains low, growth of undesirable gas-forming bacteria (such as coliforms) is favored and early blowing of the cheese can occur (Melilli et al., 2004). Reducing the brine temperature from $18^{\circ} \mathrm{C}$ to $12^{\circ} \mathrm{C}$ can reduce the incidence of early gas formation (Melilli et al., 2004). In addition, the rate of salt uptake in cheese is influenced by brine concentration, and salt diffuses faster into cheese when a nonsaturated brine is used (Resmini et al., 1974). For
Ragusano cheese, using an $18 \%$ brine provides faster salt uptake than using a saturated brine (Melilli et al., 2003b, 2005). This is apparently caused by the smaller outward migration of water that occurs when using lower concentration brines (Guinee and Fox, 2004). Having less moisture loss with lower concentration brines results in an increase in cheese yield with an $18 \%$ brine for at least the first $8 \mathrm{~d}$ of brining compared with using saturated brine (Melilli et al., 2003b, 2006). Brining a 4-kg block of Ragusano cheese in saturated brine for $24 \mathrm{~d}$ results in shrinkage of the cheese, with an overall $10 \%$ weight loss (Melilli et al., 2003a). This weight loss is the net result of an approximately $12.5 \%$ moisture loss occurring concomitantly with a $2.5 \%$ gain in weight from salt diffusion into the cheese.

Geurts et al. (1974) estimated the pore size of the protein matrix in cheese to be about $2.5 \mathrm{~nm}$. This exerts a sieving effect on both the inwardly diffusing $\mathrm{Na}^{+}$ and $\mathrm{Cl}^{-}$ions and the outward-moving $\mathrm{H}_{2} \mathrm{O}$ molecules (Guinee and Fox, 2004). During pressing of Ragusano cheese (that occurs in wooden tables with the cheese exposed to air, and some whey drainage occurs), the surface of the cheese block undergoes partial dehydration. This, combined with surface dehydration occurring during brining (Geurts et al., 1972) and subsequent storage, eventually produces a 4-mm-thick rind on Ragusano cheese (Melilli et al., 2003b). Development of such a compressed protein matrix resulting either from pressing or during brining would further impede the penetration of salt into Ragusano cheese.

Calcium is also an important factor in brining of cheeses, and the initial surface dehydration during brining occurs faster when the brine lacks calcium (Geurts et al., 1972). This rapid loss of moisture (within $2 \mathrm{~h}$ for Gouda cheese) is followed by a slower loss of calcium from the cheese surface layer and a consequent increase in surface moisture content above its original level. Thus, swelling or shrinkage of cheese during brining can depend on both brine salt and calcium concentrations (Geurts et al., 1972) and temperature (McMahon et al., 2009) and interactions between these factors. For example, softening of the cheese surface when using a weak brine can be avoided by increasing the calcium content of the brine (Geurts et al., 1972).

Such changes in moisture content of cheese occur only in those regions in which some salt has penetrated (Geurts et al., 1972). Thus, while the outer portions of the cheese are responding to high salt levels, the interior portions of the cheese block are responding to progressively lower salt concentrations. This implies that different portions of the cheese block will tend to become more hydrated or dehydrated - for the protein matrix to expand or contract - based upon the chemical environment being experienced. Our goal was to study 
the conditions under which the cheese matrix contracts or expands in response to salt and calcium concentrations and temperature in the absence of restrictions imposed by surface rind development during overnight block formation.

\section{MATERIALS AND METHODS}

\section{Cheese Making and Sampling}

Ragusano curd, made according to the traditional procedure, was purchased from a farm in the Hyblean area of Sicily and transported to the CoRFiLaC pilot plant (Ragusa, Italy). It was cut into strips and $4-\mathrm{kg}$ batches were manually stretched at 3 different temperatures $\left(70,80\right.$, and $\left.90^{\circ} \mathrm{C}\right)$. The hot cheese was formed into a coherent block and then shaped into cubes using a traditional wooden tool ("mastredda") and allowed to cool overnight at room temperature $\left(\sim 23^{\circ} \mathrm{C}\right)$. The following day, the outer $6-\mathrm{mm}$ was cut from the block surface to eliminate any interference from the rind that had formed through surface dehydration. The remainder of the cheese was cut into $3 \times 3 \times 6 \mathrm{~mm}$ pieces weighing 40 to $50 \mathrm{~g}$.

\section{Brining Cheese}

Two different series of brine solutions were prepared: (1) $10 \% \mathrm{NaCl}$ with $0,0.1,0.2$, or $0.4 \% \mathrm{Ca}$; and (2) $0.1 \%$ Ca with $2,10,18$, or $26 \% \mathrm{NaCl}$. The combination of $10 \% \mathrm{NaCl}$ and $0.1 \% \mathrm{Ca}$ served as a common treatment in both brine series. Calcium concentration was varied for the $10 \% \mathrm{NaCl}$ because we were interested in what happened at the lower levels of salt. Previous work has indicated that salt absorption is speeded up at lower brine levels (Melilli et al., 2005). A portion of each brine solution was tempered to 4,12 , or $20^{\circ} \mathrm{C}$. Each piece of cheese was accurately weighed and its volume measured by displacement; then the cheese sample was placed in a plastic bag. Three hundred milliliters of brine was added, and the bag was sealed and stored at 4,12 , or $20^{\circ} \mathrm{C}$. After $6 \mathrm{~h}$, the cheese was removed from the bag, weighed, and placed in a plastic bag with a fresh $300-$ $\mathrm{mL}$ aliquot of the appropriate brine. The cheeses were stored for an additional $18 \mathrm{~h}$ and then analyzed for weight, volume, chemical, and microstructural changes.

\section{Cheese Composition Analysis}

Moisture content was determined by drying a $3-\mathrm{g}$ sample in a forced-air oven at $100^{\circ} \mathrm{C}$ for $24 \mathrm{~h}$ (APHA, 2004). Total nitrogen was measuring by Kjeldahl method using a 1-g sample size (ISO/TS 17837:2008/ IDF/RM 25; ISO, 2008b) with conversion to protein content using a factor of 6.38. Calcium content was measured using a complexometric method (Kindstedt and Kosikowski, 1985). Ash was measured using method 932.42 of AOAC (2000), and salt was calculated as ash minus $3 \times$ calcium. Fat content of cheese was determined by Van Gulik method (ISO, 2008a). All testing was performed in duplicate.

\section{Microstructural Analysis}

Small slices $(13 \times 3 \times 1 \mathrm{~mm})$ were taken from the central portion of each piece of cheese and prepared for scanning electron microscopy by the cryofracturing technique according to McManus et al. (1993). Samples were dried to critical point in a Polaron CPD 7501 (Polaron, Watford, UK) with $\mathrm{CO}_{2}$. Dried samples were mounted on aluminum stubs using a carbon adhesive (SPI Supplies Structure Probe, West Chester, PA) and coated with gold-palladium for $15 \mathrm{~s}$ in a Polaron SC7620 mini sputter coater (Polaron). Samples were examined by JSM-5900 LV scanning electron microscope (Jeol, Tokyo, Japan) operating at an accelerating voltage of $5 \mathrm{kV}$, a working distance of 10 to $17 \mathrm{~mm}$, and a magnification of $400 \times$. To avoid observer bias in selection of fields to compare, 5 fields were used for digital imaging as shown in Figure 1. For each sample, 5 scanning electron microscopy images were recorded and quantitatively analyzed using Image $\mathrm{J}$ software (http://rsbweb.nih.gov/ij/) equipped with a "Pore Analysis" plug-in (Impoco et al., 2006). Porosity, average pore area, and pore count were calculated. Porosity was measured as the percentage of pore area relative to the total sampled area.

\section{Experimental Design and Statistical Analysis}

The 3 blocks of cheese (from the 3 stretching temperatures) were used as replicates for statistical analysis of chemical and physical changes in the cheeses brought by the different brining treatments. Data were analyzed using the Generalized Linear Models (GLM) procedure of SAS (version 9.1, 2002-2003, SAS Institute Inc., Cary, NC) in 2 separate 2 -way factorial $(4 \times 3)$ designs. The REGWQ test was used to detect differences between means of volumes and weight after $24 \mathrm{~h}$ for different amounts of salt and calcium in the brine, with a significance value of $\alpha=0.05$.

\section{RESULTS AND DISCUSSION}

\section{Before Brining}

Composition of the curd before hot-water stretching was $479 \mathrm{~g} / \mathrm{kg}$ moisture, $238 \mathrm{~g} / \mathrm{kg}$ protein, $44.9 \%$ fat- 
on-dry-basis (FDB), and pH 5.13, indicating adequate acid development in the curd during overnight fermentation before it was cut into pieces and stretched. The traditional hot-water temperature for stretching Ragusano curd is approximately $85^{\circ} \mathrm{C}$ (Licitra et al., 1998) although water temperatures as low as $73^{\circ} \mathrm{C}$ have also been used (Melilli et al., 2003b). In this experiment, the 3 batches of cheese were stretched using water at 70,80 , and $90^{\circ} \mathrm{C}$ to cover the range of potential stretching conditions and to provide a generalized set of cheeses for the brining experiment. Composition of the 3 cheeses after stretching is shown in Table 1 and was within the expected range for Ragusano cheese (Licitra et al., 1998; Melilli et al., 2003a, 2006). The 3 stretched cheeses were similar in composition, especially those stretched at 70 and $80^{\circ} \mathrm{C}$. A trend was observed of the cheese increasing in FDB and $\mathrm{pH}$. This suggests a greater loss of soluble components (lactose, lactate, salt, and $\mathrm{H}^{+}$ions into the water at the higher temperatures. Moisture content of the cheese stretched at $90^{\circ} \mathrm{C}$ was also higher than in those stretched at 70 and $80^{\circ} \mathrm{C}$. Because the stretching temperature did not make any difference in the salting results (data not shown), the 3 blocks of cheese were used as replicates. The variations caused by stretching temperature might be considered comparable to those occurring if the cheeses were made in 3 different trials where the stretching temperature was not under control.

\section{Composition After Brining}

Significance of factors influencing cheese composition is shown in Table 2 and Table 3. Brine salt concentration influenced $(P<0.01)$ moisture, protein, FDB, salt, salt-in-moisture $(\mathbf{S} / \mathbf{M})$, and calcium content of the cheese. Calcium levels in the brine also influenced all these parameters except for FDB $(P=0.28)$. Brine temperature did not influence cheese composition either as an independent variable $(P=0.06$ to 0.99$)$ or as an interaction with $\mathrm{NaCl}(P=0.25$ to 0.99$)$ or $\mathrm{Ca}$ $(P=0.66$ to 0.99$)$ content of the brine. This is the opposite of what had been observed during the brining of feta cheese, where lower moistures were observed as

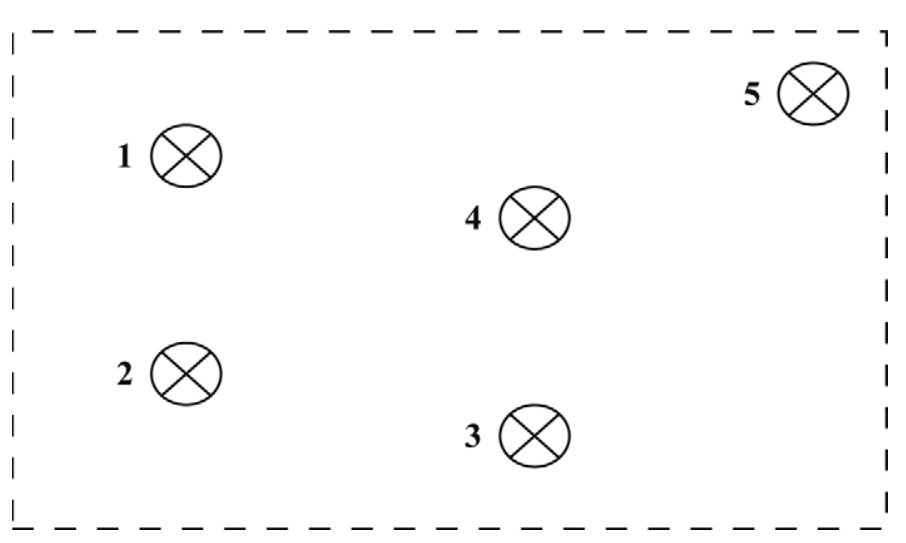

Figure 1. Scheme showing the fields selected for imaging in samples of cheese prepared for examination using scanning electron microscopy.

the brine temperature was increased from $3{ }^{\circ} \mathrm{C}$ to $22^{\circ} \mathrm{C}$ (McMahon et al., 2009).

Pooled composition of the cheese after $24 \mathrm{~h}$ of brining in the various salt and calcium combinations is shown in Table 4. Moisture contents ranged from $565 \mathrm{~g} / \mathrm{kg}$ in cheese brined at $4^{\circ} \mathrm{C}$ in the lowest salt concentration $(2 \% \mathrm{NaCl})$ to $280 \mathrm{~g} / \mathrm{kg}$ in cheese brined at $20^{\circ} \mathrm{C}$ in the highest salt concentration $(26 \% \mathrm{NaCl})$. Such lowering of moisture content with increasing salt concentration in the brine is well known (O'Connor, 1971; Sutherland, 1974; Jordan and Cogan, 1993; Kelly et al., 1996).

Some tendency was observed for slightly lower moisture content ( $\sim 8$ to $18 \mathrm{~g} / \mathrm{kg}$ reduction) in the cheese as the temperature of brining increased from $4^{\circ} \mathrm{C}$ to $20^{\circ} \mathrm{C}$. This was observed in all cheeses except for the cheese brined in $10 \% \mathrm{NaCl}$ with no added calcium, which exhibited the opposite effect. The differences in moisture were greatest at high salt levels in the brine and the least difference was observed when calcium levels were increased to 0.2 or $0.4 \%$. Increasing the calcium content in the brine also produced cheese with lower moisture. Moisture contents of $512 \mathrm{~g} / \mathrm{kg}$ were obtained when cheese was brined in $10 \%$ salt with no added calcium compared with $416 \mathrm{~g} / \mathrm{kg}$ in brine containing $0.4 \%$ calcium (Table 4).

Table 1. Proximate composition $(\mathrm{g} / \mathrm{kg})$ of cheese before and after stretching in 70,80 , or $90^{\circ} \mathrm{C}$ water

\begin{tabular}{lcccc}
\hline $\begin{array}{l}\text { Stretch water } \\
\text { temperature }\left({ }^{\circ} \mathrm{C}\right)\end{array}$ & Moisture & Protein & FDB $^{1}$ & $\mathrm{pH}$ \\
\hline Before $^{2}$ & 470 & 238 & 449 & 5.13 \\
70 & 473 & 247 & 469 & 5.15 \\
80 & 468 & 251 & 473 & 5.21 \\
90 & 491 & 246 & & 5.22 \\
\hline${ }^{1}$ Fat-on-dry-basis. & & & &
\end{tabular}


Table 2. Mean square (and $P$-value) for effect of $\mathrm{NaCl}$ levels $(\mathrm{n}=4)$ and temperature $(\mathrm{n}=3)$ of brine on chemical composition and change in weight and volume of Ragusano cheese after $24 \mathrm{~h}$ of brining

\begin{tabular}{|c|c|c|c|}
\hline \multirow[b]{2}{*}{$\begin{array}{l}\text { Dependent } \\
\text { variable }\end{array}$} & \multicolumn{3}{|c|}{ Mean square ( $P$-value) } \\
\hline & $\mathrm{NaCl}$ & Temperature & $\begin{array}{c}\mathrm{NaCl} \times \\
\text { temperature }\end{array}$ \\
\hline Moisture & $1,171(<0.01)$ & $7.243(0.20)$ & $0.466(0.99)$ \\
\hline Protein & $142(<0.01)$ & $1.797(0.22)$ & $0.262(0.96)$ \\
\hline Fat-on-dry-basis & $0.033(<0.01)$ & $0.003(0.57)$ & $0.0008(0.98)$ \\
\hline Salt & $34.84(<0.01)$ & $0.30(0.06)$ & $0.1(0.25)$ \\
\hline Salt-in-moisture & $630(<0.01)$ & $1.026(0.16)$ & $0.72(0.26)$ \\
\hline $\mathrm{Ca}$ & $0.158(<0.01)$ & $0.0018(0.56)$ & $0.0019(0.71)$ \\
\hline $\mathrm{pH}$ & $0.194(<0.01)$ & $0.0008(0.71)$ & $0.0008(0.90)$ \\
\hline Weight change & $489(<0.01)$ & $43.48(<0.01)$ & $5.30(0.08)$ \\
\hline Volume change & $502(<0.01)$ & $81.40(0.01)$ & $18.8(0.01)$ \\
\hline
\end{tabular}

It is commonly observed (O'Connor, 1971; Thakur et al., 1973) that higher salt contents in cheese coincide with higher fat and protein contents. This relates to greater losses of moisture that occur as a function of whey syneresis induced by salting of Cheddar cheese curd and by immersion of cheese into high salt concentration brines. In this study, fat and protein contents of the cheese were inversely related to moisture content. This was observed for the effects of salt and calcium content of the brine as well as brining temperature.

The uptake of salt by the cheeses during brining has a diluting effect on the amount of protein per kilogram of cheese, but this is not sufficient to counteract the effect of moisture. For cheese brined in $2 \% \mathrm{NaCl}$, mean protein content expressed on a dry basis was $47.1 \%$, whereas it was only $42.5 \%$ when brined in $26 \% \mathrm{NaCl}$. The influence of moisture uptake or loss during brining was more apparent when the cheeses brined in $10 \%$ $\mathrm{NaCl}$ with the different calcium levels were compared. With no added calcium, the cheese had mean composition of $512 \mathrm{~g} / \mathrm{kg}$ moisture with $43.4 \%$ protein on a dry basis. With $0.4 \% \mathrm{Ca}$ in the brine, the cheese moisture was only $416 \mathrm{~g} / \mathrm{kg}$ (a $19 \%$ difference), yet protein expressed on a dry basis increased only slightly to $44.8 \%$.
Fat content of the brined cheeses, when expressed on a dry basis, was similar for all cheeses except for that brined in $2 \% \mathrm{NaCl}$. Cheeses brined in 10 to $26 \% \mathrm{NaCl}$ had mean FDB in the range of 44 to $48 \%$, whereas cheese from the $2 \% \mathrm{NaCl}$ brine had $55 \%$ FDB. Cheeses with lower salt content would be expected to have higher FDB; however, the finding that cheeses from the 10 and $26 \% \mathrm{NaCl}$ brines had the same FDB was unexpected and the reason for this is unknown.

Salt content of the cheese increased as expected with increased salt concentration in the brine, and ranged from $108 \mathrm{~g} / \mathrm{kg}$ in the cheese brined in $2 \% \mathrm{NaCl}$ to $807 \mathrm{~g} /$ $\mathrm{kg}$ in cheese brined in $26 \% \mathrm{NaCl}$. In this experiment, the cheese to brine ratio was about 1:6, and a fresh portion of brine was added after $6 \mathrm{~h}$ to help compensate for the dilution effect as water diffused from the cheese into the brine. The final S/M contents of the cheeses were 1.9, $9.4,13.5$, and $21.6 \%$ after a total of $24 \mathrm{~h}$ immersion in $2,10,18$, and $26 \% \mathrm{NaCl}$ brines, respectively. The failure of the cheeses immersed in higher concentration brines (i.e., 18 and $26 \% \mathrm{NaCl}$ ) to reach equilibrium suggested that flow of sodium and chloride ions into the cheeses was more impeded and more time would be required to reach equilibrium between the cheese and brine.

Table 3. Mean square (and $P$-value) for effect of Ca level $(\mathrm{n}=4)$ and temperature $(\mathrm{n}=3)$ of brine on chemical composition and change in weight and volume of Ragusano cheese after $24 \mathrm{~h}$ of brining

\begin{tabular}{lccc}
\hline & & Mean square $(P$-value $)$ & \\
\cline { 2 - 4 } $\begin{array}{l}\text { Dependent } \\
\text { variable }\end{array}$ & $\mathrm{Ca}$ & Temperature & $\begin{array}{c}\text { Ca } \times \\
\text { temperature }\end{array}$ \\
\hline Moisture & $151.40(<0.01)$ & $0.884(0.84)$ & $0.783(0.99)$ \\
Protein & $41.38(<0.01)$ & $0.7523(0.30)$ & $0.408(0.66)$ \\
Fat-on-dry-basis & $0.002(0.28)$ & $0.0002(0.85)$ & $0.0005(0.90)$ \\
Salt & $2.87(<0.01)$ & $0.060(0.66)$ & $0.043(0.92)$ \\
Salt-in-moisture & $1.07(0.02)$ & $0.089(0.73)$ & $0.138(0.80)$ \\
Ca & $0.232(<0.01)$ & $0.00008(0.99)$ & $0.0015(0.95)$ \\
pH & $0.106(<0.01)$ & $0.0001(0.96)$ & $0.001(0.89)$ \\
Weight change & $120(<0.01)$ & $25.97(<0.01)$ & $3.03(0.56)$ \\
Volume change & $122(<0.01)$ & $74.81(0.01)$ & $7.71(0.52)$ \\
\hline
\end{tabular}


Table 4. Mean composition for cheeses brined for $24 \mathrm{~h}$ in $2,10,18$, or $26 \% \mathrm{NaCl}$ solutions (all containing $0.1 \%$ $\mathrm{Ca}$ ) or in $10 \% \mathrm{NaCl}$ solutions containing $0,0.1,0.2$, or $0.4 \% \mathrm{Ca}$ with data pooled from all brining temperatures

\begin{tabular}{lcccccc}
\hline $\begin{array}{l}\text { Brine } \\
\text { parameter }\end{array}$ & $\begin{array}{c}\text { Moisture } \\
(\mathrm{g} / \mathrm{kg})\end{array}$ & $\begin{array}{c}\text { Salt } \\
(\mathrm{g} / \mathrm{kg})\end{array}$ & $\begin{array}{c}\mathrm{FDB}^{1} \\
(\%)\end{array}$ & $\begin{array}{c}\text { Protein } \\
(\mathrm{g} / \mathrm{kg})\end{array}$ & $\begin{array}{c}\mathrm{Ca} / \mathrm{protein} \\
(\mathrm{g} / \mathrm{kg})\end{array}$ & $\mathrm{pH}$ \\
\hline $\mathrm{NaCl}(0.1 \% \mathrm{Ca})$ & & & & & & \\
$2 \%$ & $561^{\mathrm{a}}$ & $10.8^{\mathrm{a}}$ & $57.2^{\mathrm{a}}$ & $207^{\mathrm{a}}$ & $26.7^{\mathrm{a}}$ & $5.25^{\mathrm{a}}$ \\
$10 \%$ & $458^{\mathrm{b}}$ & $47.3^{\mathrm{b}}$ & $44.8^{\mathrm{b}}$ & $239^{\mathrm{b}}$ & $27.5^{\mathrm{a}}$ & $5.10^{\mathrm{b}}$ \\
$18 \%$ & $376^{\mathrm{c}}$ & $60.4^{\mathrm{c}}$ & $47.3^{\mathrm{b}}$ & $270^{\mathrm{c}}$ & $25.6^{\mathrm{a}}$ & $4.99^{\mathrm{c}}$ \\
$26 \%$ & $293^{\mathrm{d}}$ & $80.7^{\mathrm{d}}$ & $44.2^{\mathrm{b}}$ & $300^{\mathrm{d}}$ & $28.9^{\mathrm{a}}$ & $4.91^{\mathrm{d}}$ \\
$\mathrm{Ca}(10 \% \mathrm{NaCl})$ & & & & & & \\
$0 \%$ & $512^{\mathrm{a}}$ & $52.3^{\mathrm{a}}$ & $48.3^{\mathrm{a}}$ & $211^{\mathrm{a}}$ & $23.3^{\mathrm{a}}$ & $5.20^{\mathrm{a}}$ \\
$0.1 \%$ & $458^{\mathrm{b}}$ & $47.5^{\mathrm{b}}$ & $44.8^{\mathrm{a}}$ & $239^{\mathrm{b}}$ & $27.5^{\mathrm{b}}$ & $5.10^{\mathrm{b}}$ \\
$0.2 \%$ & $439^{\mathrm{b}}$ & $42.6^{\mathrm{c}}$ & $46.3^{\mathrm{a}}$ & $249^{\mathrm{c}}$ & $30.0^{\mathrm{bc}}$ & $5.06^{\mathrm{b}}$ \\
$0.4 \%$ & $416^{\mathrm{c}}$ & $39.4^{\mathrm{c}}$ & $47.2^{\mathrm{a}}$ & $262^{\mathrm{d}}$ & $32.2^{\mathrm{c}}$ & $4.94^{\mathrm{c}}$ \\
\hline
\end{tabular}

${ }^{\mathrm{a}-\mathrm{d}}$ Means within columns for each brine parameter with the same letter were not significantly different $(\alpha=$ $0.05)$.

${ }^{1}$ Fat-on-dry-basis.

Calcium content of the cheeses decreased from 8.6 to $5.5 \mathrm{~g} / \mathrm{kg}$ as the $\mathrm{NaCl}$ content of the brine was decreased from 26 to $2 \%$, respectively. This, however, was a function of increased moisture content of the lower salt cheeses, and when calculated on a protein basis, the cheeses all had calcium contents of 26 to $29 \mathrm{~g} / \mathrm{kg}$ protein (Table 4). This implied that no displacement of $\mathrm{Ca}$ by $\mathrm{Na}$ ions occurred from the proteins as the salt diffused into the cheese from the brine. This agrees with Pastorino et al. (2003b), who also observed no increase in soluble Ca when $\mathrm{NaCl}$ solutions were injected into cheese. Varying the level of $\mathrm{Ca}$ in the brine did alter the ratio of $\mathrm{Ca}$ to protein in the cheese, from 22 $\mathrm{g} / \mathrm{kg}$ protein, when no $\mathrm{Ca}$ was added to the brine, to $33 \mathrm{~g} / \mathrm{kg}$ protein, when $0.4 \% \mathrm{Ca}$ was included in a $10 \%$ $\mathrm{NaCl}$ brine solution. The levels of insoluble calcium in the cheeses were not measured but we assumed that some of the soluble Ca from the brine would bind to the proteins and become part of the colloidal calcium phosphate that forms crosslinks between the phosphoserine side chains of the caseins.

The $\mathrm{pH}$ of the cheeses after brining was dependent on both $\mathrm{NaCl}$ and $\mathrm{Ca}$ content of the brine, with lower $\mathrm{pH}$ occurring in cheeses brined with either higher $\mathrm{NaCl}$ or higher Ca levels. Each of the brine solutions had initially been adjusted to $\mathrm{pH} 5.2$ to match the $\mathrm{pH}$ of the cheese before brining. When the brine contained either $2 \% \mathrm{NaCl}$ with $0.1 \% \mathrm{Ca}$ or $10 \% \mathrm{NaCl}$ with $0 \% \mathrm{Ca}$, the $\mathrm{pH}$ of the cheese after $24 \mathrm{~h}$ of brining remained at about $\mathrm{pH} 5.2$ (see Table 4). Increasing the $\mathrm{NaCl}$ in the brine to $26 \%$ produced a cheese with $\mathrm{pH} 4.9$. The same effect was observed when the Ca level in the $10 \% \mathrm{NaCl}$ brine was increased to $0.4 \%$. Pastorino et al. (2003c) observed a similar decrease in $\mathrm{pH}$ when a Ca solution was injected into cheese. Such a lowering of $\mathrm{pH}$ requires the release of $\mathrm{H}^{+}$ions into the cheese serum.
The most likely source of $\mathrm{H}^{+}$ions in cheese would be from $\mathrm{H}_{2} \mathrm{PO}_{4}^{-}$ions being precipitated as calcium phosphate in the form of $\mathrm{Ca}_{3}\left(\mathrm{PO}_{4}\right)_{2}$, which is the most likely form of the colloidal calcium phosphate in cheese (Lucey and Horne, 2009). It is easy to understand how increasing the calcium content of the brine would shift the position of the calcium phosphate equilibrium to an increase in insoluble calcium phosphate but it is less clear why this occurs with an increase in $\mathrm{NaCl}$.

\section{Salt Concentration}

Cheese Weight. Each cheese sample was weighed before brining and after 6 and $24 \mathrm{~h}$ (with fresh brine solution added at $6 \mathrm{~h}$ ). Use of different salt concentrations in brine significantly $(P<0.01)$ influenced the weight of the cheese after brining (Table 2). As the brine salt concentration decreased, cheese weight increased linearly. When the cheese was brined in a saturated $26 \%$ salt brine, cheese weight declined by $10 \%$ to $20 \%$ (Figure $2 \mathrm{~A}$ ). Conversely, when a $2 \%$ salt brine was used, the cheeses gained up to $25 \%$ of their original weight during the $24-\mathrm{h}$ brining process. Cheese weight differed significantly after brining at each salt concentration $(2,10,18$, and $26 \%)$.

Changes in weight induced by altering the brining temperature were sufficient to reach statistical significance $(P<0.01)$. Despite the similarity of cheeses brined at $4^{\circ} \mathrm{C}$ and $12^{\circ} \mathrm{C}$, differences in the amount of weight lost after $24 \mathrm{~h}$ in the $18 \%$ brine were observed. When the temperature was increased to $20^{\circ} \mathrm{C}$, the cheeses had lower weights (Figure 2A), with less weight gain occurring in the $2 \%$ brine (i.e., a weight gain of $12 \%$ compared with $\sim 25 \%$ ), and more weight loss in the saturated brine (i.e., a weight loss of $19 \%$ compared with $\sim 13 \%$ ). 

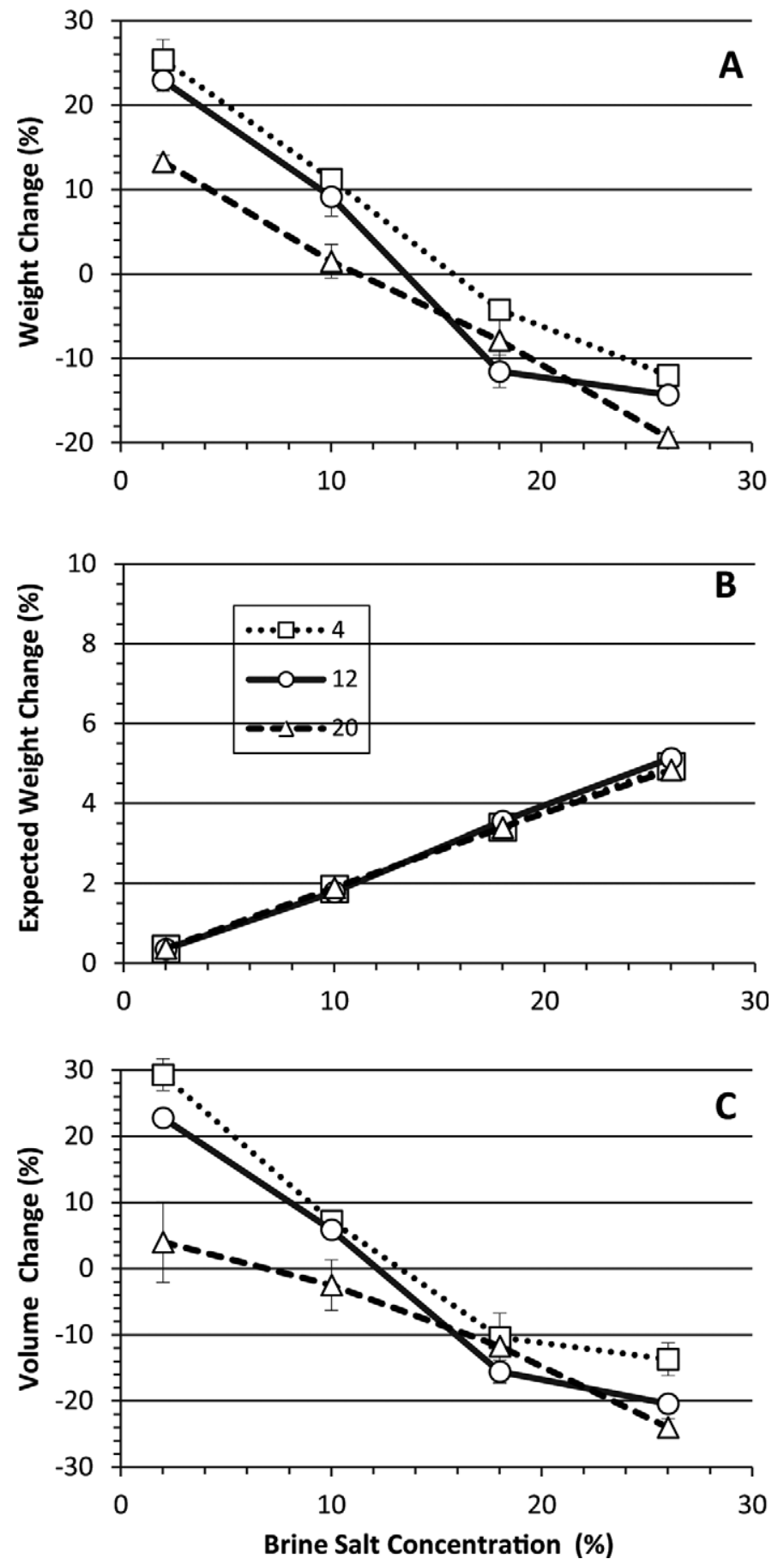

Figure 2. Physical changes occurring in Ragusano cheese that has been immersed for $24 \mathrm{~h}$ at 4,12 , and $20^{\circ} \mathrm{C}$ in brines containing 2, 10, 18 , and $26 \% \mathrm{NaCl}$ and $0.1 \% \mathrm{Ca}$. Error bars are SE.

Cheese Volume. If change in weight was a function of absorption of salt, then weight gain should be in proportion to salt concentration of the brine (Figure 2B). Generally, when cheese is brined, water flows from the cheese into the brine (Geurts et al., 1974) by an osmotic effect induced by the high salt concentration
$(>20 \%)$ of the brine. At low salt concentrations in the brine, this osmotic effect is much smaller and the flow of moisture is in the opposite direction (i.e., into the cheese) and the cheese expands $(P<0.01)$. Brine temperature did influence volume change of the cheese $(P=0.01)$ and we found a significant interaction of temperature with salt concentration $(P=0.01)$. The greatest volume increase $(30 \%)$ occurred in the cheese stored in the $2 \%$ brine at the coldest temperature (Figure $2 \mathrm{C}$ ). Brining the cheese at $20^{\circ} \mathrm{C}$ counteracted the tendency of the cheese to expand, and the volume increase was only about $4 \%$. This is similar to that observed for Feta cheese (McMahon et al., 2009). Mean volume of cheeses after $24 \mathrm{~h}$ in 2,10 , and $18 \%$ brines were significantly different but no significant difference was found between cheeses in the 18 and $26 \%$ brines.

Based on the crossover from cheese expansion in $10 \%$ salt brine (when containing $0.1 \% \mathrm{Ca}$ ) to cheese shrinkage in $18 \%$ salt brine (Figure 2A), it was estimated that cheese in approximately $13 \%$ salt brine (at 12 or $20^{\circ} \mathrm{C}$ ) would exhibit no weight change during brining, implying that cheese volume would decrease slightly to compensate for the increased density of the cheese as salt is absorbed. If the only factor influencing moisture diffusion were the $\mathrm{S} / \mathrm{M}$ concentration gradient, then we would expect the cheese to lose moisture and shrink. We suggest that osmotic pressure alone does not control diffusion of water in the cheese but is also influenced by the balance of protein-protein interactions within the protein matrix of the cheese and protein-water interactions.

At $2 \%$ salt concentrations, the osmotic effect promoting diffusion of water out of the cheese is very small, whereas protein-protein interactions are weakened as the proteins increase in solubility (Paulson et al., 1998) and the protein matrix expands. Inhibition of protein matrix expansion occurs at higher temperatures $\left(20^{\circ} \mathrm{C}\right)$ because hydrophobic interactions between proteins become more relevant to the free energy of the system. Then, as salt concentration is increased, the concentration gradient between the cheese and the brine increases such that osmotic pressure increases in magnitude and the balance of forces now results in shrinkage of the cheese.

\section{Calcium}

Varying calcium content in $10 \%$ salt brines significantly $(P<0.01$; Table 3$)$ influenced weight change of the cheese, as shown in Figure 3. At $0.4 \% \mathrm{Ca}$, virtually no change occurred at any temperature, cheese weight decreased with $0.2 \% \mathrm{Ca}$ at $20^{\circ} \mathrm{C}$, whereas cheese weight increased for all the other combinations of $\mathrm{Ca}$ and temperature. The greatest weight yield was at $4^{\circ} \mathrm{C}$ with $0 \%$ 
Ca in the brine. Temperature was a significant source of variation of weight $(P<0.01)$ and volume $(P=0.01)$ changes in cheese (Table 3 ).

Volume of the cheese after brining was inversely related to calcium content in the brine (Figure 3). Changes in volume indicate that protein matrix structure is either expanding or contracting. An absence of calcium caused a volume increase at all temperatures, with low temperatures $\left(4^{\circ} \mathrm{C}\right)$ causing the largest increase. In contrast, a combination of high temperature $\left(20^{\circ} \mathrm{C}\right)$ and high calcium percentage $(0.4 \%)$ resulted in a decrease in cheese volume. Interestingly, at these conditions, the approximately $20 \%$ volume decrease of cheese immersed in a $10 \% \mathrm{NaCl}$ brine was about the same as what occurred with a $26 \% \mathrm{NaCl}$ brine containing $0.1 \%$ calcium. When changes in cheese weight and volume based on change in $\mathrm{NaCl}$ or $\mathrm{Ca}$ concentrations (Figure 2 and Figure 3, respectively) were compared, the temperature dependence was greater for calcium concentration. This suggests a difference in the basis for shrinkage of these cheeses.

When the Ca concentration of the brine is kept constant, the shrinkage of the cheese appears to follow the process described by Geurts et al. (1974). Volume reduction occurs as water molecules leave the cheese in response to osmotic pressure as salt diffuses into the cheese from the brine. However, when the $\mathrm{NaCl}$ concentration is kept constant and the Ca concentration of brine increases from 0 to $0.4 \%$, the osmotic pressure remains virtually the same. Increased displacement of water from the cheese can then be attributed to calcium-induced aggregation of proteins within the cheese and subsequent shrinkage of the cheese protein matrix. Such shrinkage has previously been shown to occur in Mozzarella cheese (McMahon et al., 2005), Cheddar cheese (Pastorino et al., 2003c), and Feta cheese (McMahon et al., 2009). Shrinkage of the cheese protein matrix also occurs as the temperature is increased because of increased casein aggregation as the importance of hydrophobic interactions increases (Pastorino et al., 2002). The shrinkage-induced flux of water out of the cheese would potentially impede diffusion of $\mathrm{Na}^{+}$and $\mathrm{Cl}^{-}$ions into the cheese during the brining process. This would then account for the decreased $\mathrm{NaCl}$ content of the cheeses as Ca concentration in the brine was increased (Table 4). When considered on an aqueous concentration basis, $\mathrm{S} / \mathrm{M}$ levels decreased from a mean of $9.27 \%$ when no calcium was added to the brine, to a mean of $8.65 \%$ when $0.4 \%$ calcium was in the brine.

\section{Cheese Microstructure}

Microstructure of the Ragusano cheeses coincided with observed changes in chemical composition and
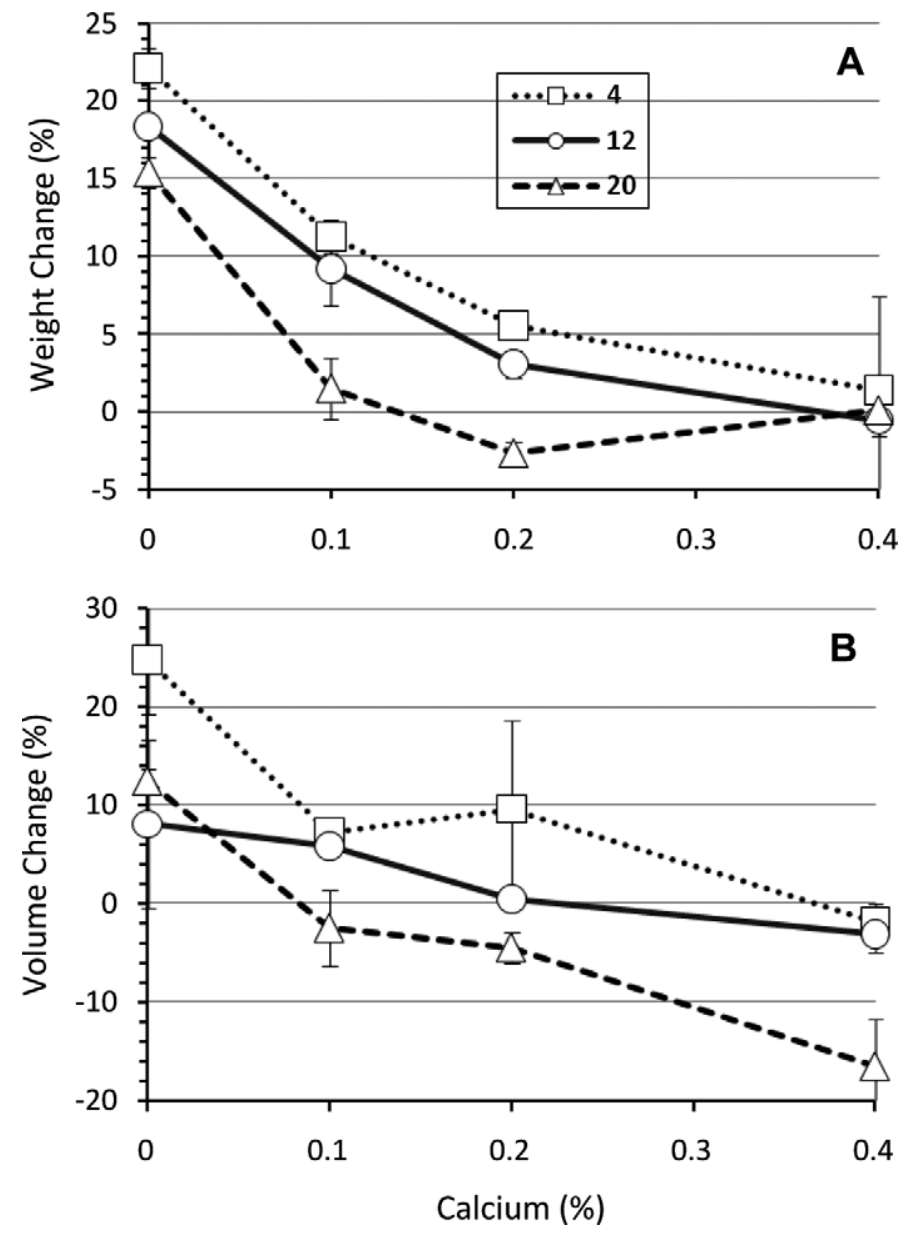

Figure 3. Physical changes occurring in Ragusano cheese that has been immersed for $24 \mathrm{~h}$ at 4,12 , and $20^{\circ} \mathrm{C}$ in brines containing $10 \%$ $\mathrm{NaCl}$ and $0,0.1,0.2$, and $0.4 \% \mathrm{Ca}$. Error bars are SE.

volume of the cheese. At $20^{\circ} \mathrm{C}$, brining in the lowest salt level of $2 \% \mathrm{NaCl}$ produced only a $4 \%$ increase in volume (Figure 2), and the protein matrix of this cheese (Figure 4A) appeared more expanded than cheese brined at $10 \% \mathrm{NaCl}$ (Figure $5 \mathrm{~A}$ ) that had a $3 \%$ decrease in volume. When the porosity of the cheese in these images was quantified as the porosity mean of the 5 fields observed, the cheese brined in $10 \% \mathrm{NaCl}$ had a porosity mean value of $12.6 \%$ (Figure $5 \mathrm{~B}$ ), whereas the porosity of the cheese from the $2 \%$ brine was $14.4 \%$ (Figure 4B). The higher salt cheese had smaller (area mean value 13.65 vs. $21.86 \mu \mathrm{m}$ ) and more numerous $(1,475$ vs. 1,046$)$ pores, confirming that shrinkage occurred in cheeses brined at $10 \% \mathrm{NaCl}$ brine.

Having a higher salt concentration in the brine causes a contraction of the cheese protein matrix that would expel whey as well as moisture by osmosis so that a net whey migration occurs from the void spaces and the protein matrix. Thus, per unit area of cheese samples viewed by electron microscopy, the pores be- 

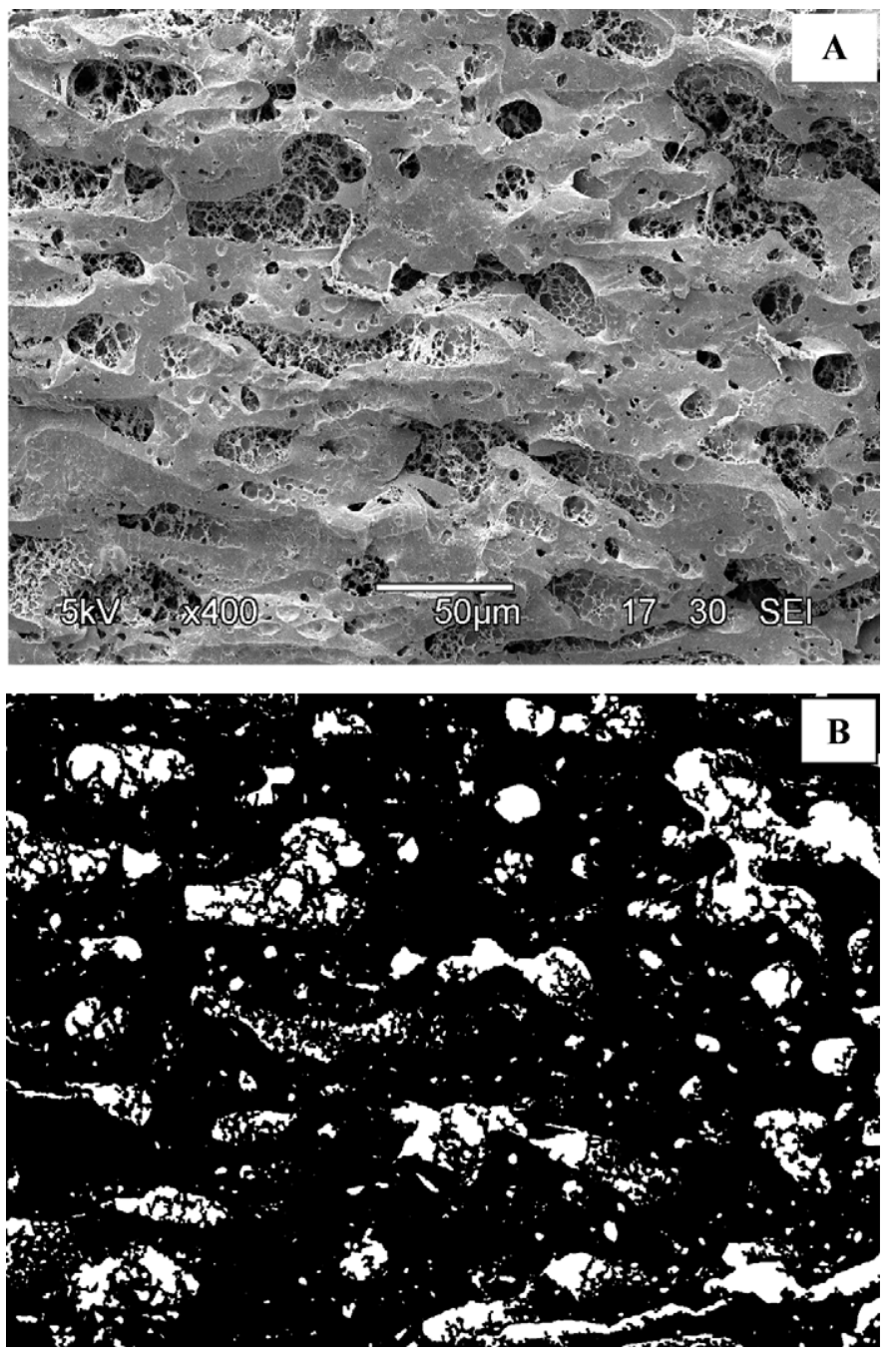

Figure 4. (A) Scanning electron micrograph of Ragusano cheese brined at $2 \% \mathrm{NaCl}, 0.1 \% \mathrm{Ca}$, and $20^{\circ} \mathrm{C}$; (B) binarized image processed using an image analysis tool.

came smaller and more numerous. The protein matrix in higher salt cheese also occupied a greater area of the microscopy field of view, $78 \%$ compared with $75 \%$.

Calcium concentration in brine (and consequent $\mathrm{Ca}$ content in the cheese) also influenced cheese microstructure. Higher $\mathrm{Ca}$ in cheese produced pores that were smaller compared with those in cheeses brined with lower Ca. Cheese brined in $10 \% \mathrm{NaCl}$ with $0.4 \% \mathrm{Ca}$ (Figure 6A) also had fewer (1,350 vs. 1,849 pores) and smaller (area mean value 14.64 vs. $18.00 \mu \mathrm{m}$ ) pores than cheese from the brine with $0.2 \% \mathrm{Ca}$ (Figure $7 \mathrm{~A}$ ). This corresponded to porosity mean values of $13.5 \%$ (Figure $6 \mathrm{~B}$ ) and $18 \%$ (Figure $7 \mathrm{~B}$ ), respectively. Thus, the loss of moisture from the pores caused by a high Ca level in the brine appears greater than that caused by high salt. McMahon et al. (2005) also showed that increasing the
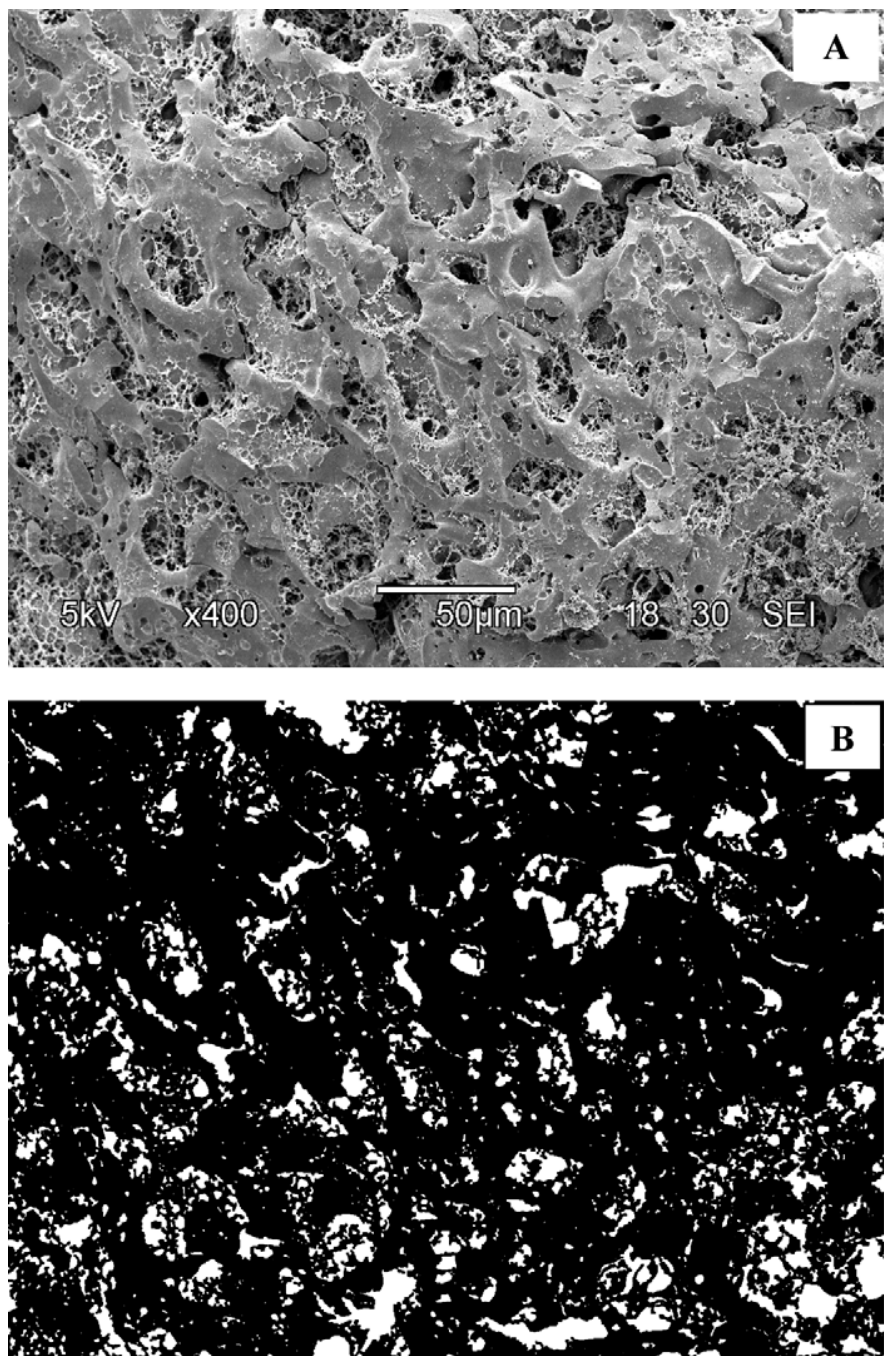

Figure 5. (A) Scanning electron micrograph of Ragusano cheese brined at $10 \% \mathrm{NaCl}, 0.1 \% \mathrm{Ca}$, and $20^{\circ} \mathrm{C}$; (B) binarized image processed using an image analysis tool.

Ca concentration in cheese induces stronger proteinprotein interactions, and less whey remains entrapped within the protein matrix. Similar observations were found by Guinee et al. (2002) and Joshi et al. (2004), in which reducing the Ca content of Mozzarella cheese led to a more hydrated and expanded protein matrix. Pastorino et al. (2003c) also reported that adding Ca to cheese causes protein fiber contraction and more whey loss, inducing shrinkage of the whole cheese structure.

\section{Brining Cheese}

The implication of these findings to Ragusano cheese is that various portions of the cheese block will be subject to different forces as the cheese is being brined, depending on the salt and calcium concentrations to 

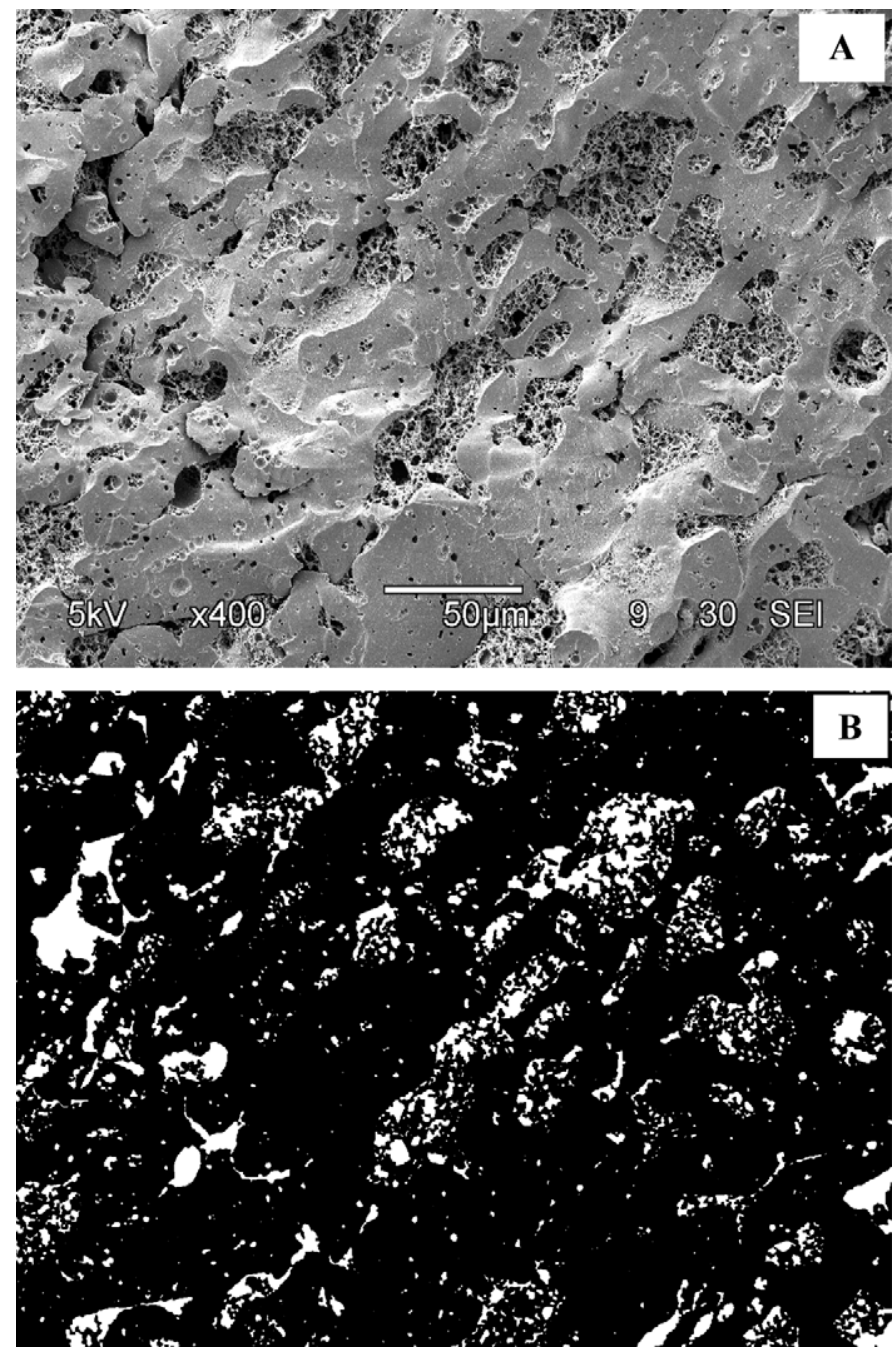

Figure 6. A) Scanning electron micrograph of Ragusano cheese brined at $10 \% \mathrm{NaCl}, 0.4 \% \mathrm{Ca}$, and $12^{\circ} \mathrm{C}$; (B) binarized image processed using an image analysis tool.

which the protein matrix is exposed. At the same time as the cheeses for this experiment were being manufactured, duplicate blocks of Ragusano cheese were made, and these were then brined in the normal manner. After brining, these cheeses were sampled at different depths and, going from the exterior layer to the central core, the cheese had increasing moisture levels of 40.3, 43.4, 45.1 , and $46.4 \%$ with corresponding $\mathrm{S} / \mathrm{M}$ levels of 9.7 , $6.7,3.9$, and $1.6 \%$. Consequently, while the protein matrix at the surface of the cheese surface is contracting and expelling moisture, the cheese at the center of the cheese resists shrinkage and, if moisture were available, the cheese would be expected to expand (Figure 2).

Cheese is criss-crossed by capillaries, and several factors can affect permeability and the diffusion of salt into the cheese. Fat globules can block the cheese mi-
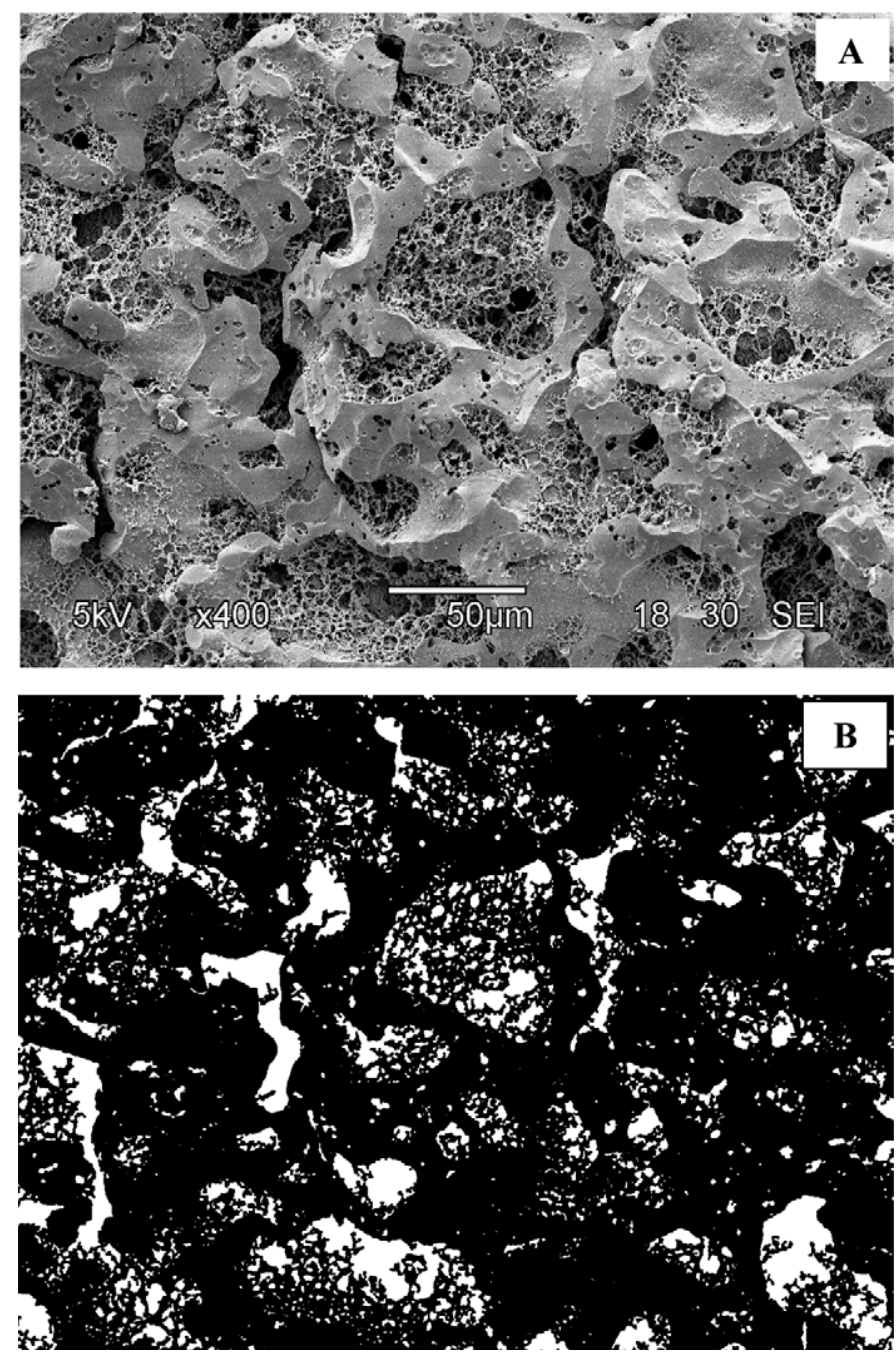

Figure 7. A) Scanning electron micrograph of Ragusano cheese brined at $10 \% \mathrm{NaCl}, 0.2 \% \mathrm{Ca}$, and $20^{\circ} \mathrm{C}$; (B) binarized image processed using an image analysis tool.

crostructure, and salt penetration will take longer in a cheese with a higher fat. The $\mathrm{pH}$ of the cheese can also influence the rate of salt absorption, with more salt being absorbed at low pH than at higher pH. Decreased $\mathrm{pH}$ values induce calcium solubility and decrease its content in the cheese (Pastorino et al., 2003a). As shown by Melilli et al. (2006), salt penetration varies with temperature, with higher temperatures promoting salt penetration, moisture loss, and weight loss during brining.

\section{CONCLUSIONS}

Ragusano cheese was salted in brines of different composition and temperatures. Salt and calcium concentrations of the brine had the greatest influence on cheese 
composition, cheese weight, and cheese volume. Cheeses immersed in $26 \% \mathrm{NaCl}$ brine and those brined in $0.4 \%$ Ca showed greater moisture loss. Because high levels of salt and calcium promote water expulsion, decreases in weight and volume were recorded. In detail, higher salt concentration in the brine enhanced expulsion of whey and moisture loss by osmosis, causing a contraction of the cheese protein matrix. High calcium levels in the brine tightened protein-protein hydrophobic interactions, favoring whey expulsion from the cheese. Results of cheese volume changes were confirmed from the porosity measurement: decreases in volume corresponded to lower cheese porosity. Brining temperature and its interaction with salt and calcium had a significant influence on volume and weight changes.

\section{ACKNOWLEDGMENTS}

The authors acknowledge the laboratory technicians of CoRFiLaC This research was funded by the Assessorato Agricoltura e Foreste of the Sicilian Region (Palermo, Italy).

\section{REFERENCES}

APHA (American Public Health Association). 2004. Standard Methods for the Examination of Dairy Products. 17th ed. APHA, Washington, DC.

AOAC. 2000. Official Methods of Analysis. 17th ed. AOAC International, Gaithersburg, MD.

Geurts, T. J., P. Walstra, and H. Mulder. 1972. Brine composition of the defect 'soft rind' in cheese. Neth. Milk Dairy J. 26:168-179.

Geurts, T. J., P. Walstra, and H. Mulder. 1974. Transport of salt and water during salting of cheese.1. Analysis of the processes involved. Neth. Milk Dairy J. 28:102-129.

Guinee, T. P., E. P. Feeney, M. A. E. Auty, and P. F. Fox. 2002. Effect of $\mathrm{pH}$ and calcium concentration on some textural and functional properties of Mozzarella cheese. J. Dairy Sci. 85:1655-1669.

Guinee, T. P., and P. F. Fox. 2004. Salt in cheese: Physical, chemical and biological aspects. Pages 207-260 in Cheese: Chemistry, Physics and Microbiology. Vol. 1 General Aspects. 3rd ed. P. F. Fox, P. L. H. McSweeney, T. M. Cogan, and T. P. Guinee, ed. Elsevier Academic Press, London, UK.

ImpocoG.CarratoS.CaccamoM.TuminelloL.LicitraG. 2006. Quantitative analysis of cheese microstructure by scanning electron microscope images. J. Dairy Sci. 89(Suppl. 1):423. (Abstr.)

ISO. 2008a. Cheese: Determination of fat content-Van Gulik method (Reference Method). ISO Standard 3433, IDF 222:2008. International Organization for Standardization, Leusden, the Netherlands.

ISO. 2008b. Processed cheese products: Determination of nitrogen content and crude protein calculation-Kjeldahl method. ISO/ TS 17837: 2008, IDF/RM 25:2008. International Organization for Standardization, Geneva, Switzerland.

Jordan, K. N., and T. M. Cogan. 1993. Identification and growth of non starter lactic acid bacteria in Irish Cheddar cheese. Ir. J. Agric. Food Res. 32:47-55.

Joshi, N. S., K. Muthukumarappan, and R. I. Dave. 2004. Effect of calcium on microstructure and meltability of part skim Mozzarella cheese. J. Dairy Sci. 87:1975-1985.

Kelly, M., P. F. Fox, and P. L. H. McSweeney. 1996. Effect of salt-inmoisture on proteolysis in Cheddar type cheese. Milchwissenschaft 51:498-501.
Kindstedt, P. S., and F. V. Kosikowski. 1985. Improved complexometric determination of calcium in cheese. J. Dairy Sci. 68:806-809.

Licitra, G., and V. Bottazzi. 2001. Il Ragusano: Formaggio d'Autore [Ragusano: A piece of art cheese]. CoRFiLaC Editor, Ragusa, Italy.

Licitra, G., J. C. Ogier, S. Parayre, C. Pediliggeri, T. M. Carnemolla, H. Falentin, M. N. Madec, S. Carpino, and S. Lortal. 2007. Variability of bacterial biofilm of the "tina" wood vats used in the Ragusano cheese-making process. Appl. Environ. Microbiol. 73:6980-6987.

Licitra, G., G. Portelli, P. Campo, G. Longombardo, G. Farina, S. Carpino, and D. M. Barbano. 1998. Technology to produce Ragusano cheese: A survey. J. Dairy Sci. 81:3343-3349.

Lucey, J. A., and D. S. Horne. 2009. Milk salts: Technological significance. Pages 351 to 390 in Advanced Dairy Chemistry. Vol. 3: Lactose, Water, Salts and Minor Constituents. 3rd ed. P. L. H. McSweeney and P. F. Fox, ed. Springer Science+Business Media, New York, NY.

McMahon, D. J., M. M. Motawee, and W. R. McManus. 2009. Influence of brine concentration and temperature on composition, microstructure and yield of feta cheese. J. Dairy Sci. 92:4169-4179.

McMahon, D. J., B. Paulson, and C. J. Oberg. 2005. Influence of calcium, $\mathrm{pH}$, and moisture on protein matrix structure and functionality in direct-acidified non fat Mozzarella cheese. J. Dairy Sci. 88:3754-3763.

Melilli, C., D. M. Barbano, M. Caccamo, M. A. Calvo, G. Schembari, and G. Licitra. 2004. Influence of brine concentration, brine temperature, and presalting on early gas defects in raw milk pasta filata cheese. J. Dairy Sci. 87:3648-3657.

Melilli, C., D. M. Barbano, M. Caccamo, L. Tuminello, S. Carpino, and G. Licitra. 2006. Interaction of brine concentration, brine temperature, and presalting on salt penetration in Ragusano cheese. J. Dairy Sci. 89:1420-1438.

Melilli, C., D. M. Barbano, G. Licitra, G. Portelli, G. Di Rosa, and S. Carpino. 2003a. Influence of the temperature of salt brine on salt uptake by Ragusano cheese. J. Dairy Sci. 86:2799-2812.

Melilli, C., D. M. Barbano, G. Licitra, G. Tumino, G. Farina, and S. Carpino. 2003b. Influence of presalting and brine concentration on salt uptake by Ragusano cheese. J. Dairy Sci. 86:1083-1100.

Melilli, C., D. Carcò, D. M. Barbano, G. Tumino, S. Carpino, anc G. Licitra. 2005. Composition, microstructure, and surface barrier layer development during brine salting. J. Dairy Sci. 88:23292340 .

O'Connor, C. B. 1971. Composition and quality of some commercial Cheddar cheese. Irish Agric. Creamery Rev. 26:5-6.

Pastorino, A. J., R. I. Dave, C. J. Oberg, and D. J. McMahon. 2002. Temperature effect on structure-opacity relationships of nonfat mozzarella cheese. J. Dairy Sci. 85:2106-2113.

Pastorino, A. J., C. L. Hansen, and D. J. McMahon. 2003a. Effects of $\mathrm{pH}$ on the chemical composition and structure-function relationships of Cheddar cheese. J. Dairy Sci. 86:2751-2760.

Pastorino, A. J., C. L. Hansen, and D. J. McMahon. 2003b. Effect of salt on structure-function relationships of cheese. J. Dairy Sci. 86:60-69.

Pastorino, A. J., N. P. Ricks, C. L. Hansen, and D. J. McMahon. 2003c. Effects of calcium and water injection on structure-function relationships of cheese. J. Dairy Sci. 86:105-113.

Paulson, M., D. J. McMahon, and C. J. Oberg. 1998. Influence of sodium chloride on appearance, functionality, and protein arrangements in nonfat Mozzarella cheese. J. Dairy Sci. 81 :2053-2064.

Resmini, P., G. Volonterio, S. Annibaldi, and G. Ferri. 1974. Studio sulla diffusione del sale nel formaggio Parmigiano-Reggiano mediante l'uso di $\mathrm{Na}^{36} \mathrm{Cl}$. Sci. Tecn. Latt. Cas. 25:149-166.

Sutherland, B. J. 1974. Control of salt absorption and whey drainage in Cheddar cheese manufacture. Aust. J. Dairy Technol. 29:86-93.

Thakur, M. K., J. R. Kirk, and T. I. Hedrick. 1973. Changes during ripening of unsalted Cheddar cheese. J. Dairy Sci. 58:175-180. 